\title{
Molecular Characterization of Chicken Anaemia Virus Circulating in Commercial Poultry Flocks in Egypt during 2020
}

\author{
Ahmed Abdelhalim, Abdelhafez Samir, and Nahed Yehia * \\ Reference Laboratory for Veterinary Quality Control on Poultry Production, Animal Health Research Institute, Agricultural Research Center. Giza \\ 12618, Egypt \\ *Corresponding author's Email: nahedyehia@gmail.com; (iDORCiD: 0000-0002-2823-6467
}

\begin{abstract}
Chicken Anemia Virus (CAV) is an extremely contagious immunosuppressive disease causing high economic losses in poultry production. In the present study, tissue samples (bone marrow, thymus, and spleen) were collected from 86 different broiler chicken farms located in fourteen governorates in Egypt during 2020. They suffered from retard growth, weakness, and a drop in egg production with an observed mortality rate ranged 5-15\%. A total of 26 samples were positive for CAV using PCR in six governorates in Lower Egypt with a 30\% incidence rate, especially in Sharkia (78\%), Ismailia (62.5\%), and Alexandria (60\%). The viral protein1 (VP1) gene of CAV was genetically characterized by sequencing of 10 selected viruses in six governorates. revealing that all Egyptian strains were clustered into two groups (A, B) that was distinct from vaccine strains (Del-Ros, Cux-1, and 26PA) which were clustered in group C. The seven Egyptian viruses in this study (A-Egypt-AN1-2020 to A-Egypt-AN7-2020) were clustered with the viruses from Japan, Argentina, and Malaysia in group A, and the other three viruses (A-EgyptAN8-2020, A-Egypt-AN9-2020, A-Egypt-AN10-2020) were clustered with the viruses from Nigeria, and India in group B. The Egyptian viruses in the current study acquired new specific mutations clustering them into new subgroups (2A, 2B). By mutation analysis comparing with Del-Rose reference strains, V75I, M97L, and K139Q, E144Q were recorded in all viruses in the group A and B. All Egyptian viruses in the current study had specific new mutations at Y13N, H22N. Moreover, mutation at G74E in Egyptian viruses recorded in the current study was related to sub group 2A, I83V in three strains (A/Egypt/AN1/2020, A/Egypt/AN2/2020, A/Egypt/AN4/2020), and $\mathrm{S} 140 \mathrm{~A}$ in the hypervariable region was found in four strains (A/Egypt/AN1/2020, A/Egypt/AN2/2020, A/Egypt/AN4/2020 and A/Egypt/AN5/2020) in subgroup 2A. Furthermore, Q139 and Q144 amino acid substitutions, which are important in viral replication, were observed in all viruses. The field viruses in the study were distinct from the vaccinal strains by phylogenetic analysis and A.A. identity. In conclusion, the CAV was continuously circulating in Egypt from different genotypes. It acquired new specific mutations clustering them in a new subgroup, and it was distinct from vaccinal strains. Therefore, it is important to conduct continuous monitoring on the genetic evolution of CAV and further studies on the pathogenicity of the virus and the vaccine efficacy.
\end{abstract}

Keywords: Chicken Anemia Virus, Egypt, Genetic evolution, Viral protein 1 gene

\section{INTRODUCTION}

Chicken Anaemia Virus (CAV) is an immunosuppressive pathogen leading to a barrage of economic losses for poultry breeders (Islam et al., 2002). The first detection of CAV was in Japan in 1978 (Yuasa et al., 1979). Then it was recorded and spread in different governorates in Egypt leading to high economic losses (Erfan et al., 2018).

The Chicken Anaemia Virus causes high economic losses, especially in broiler chickens. Chickens of all ages are vulnerable to infection, but the chickens less than two weeks old commonly represent the clinical diseases (Miller and Schat, 2004; Cheng et al., 2019). The infection is characterized mainly by anemia, weight loss, and lymphoid atrophy accompanied by immunosuppression that leads to an increase in the susceptibility of secondary bacterial and viral infection. The mortality and morbidity rates due to CAV infection reach 55-80\% (Lai et al., 2018).

Chicken Anemia Virus (CAV) is a non-enveloped virus and has a negative-sense genome (Peters et al., 2006) that consists of three overlapping open reading frames encoding to three viral proteins (VP1, VP2, and VP3). The VP1 capsid protein is an important major structural protein. The VP2 protein is a dual-specificity protein that acts as a scaffold to phosphatase activity to assist the correct assemblage of VP1 protein (Craig et al., 2009; Rosario et al., 2017). The VP3 protein called apoptin is the primary factor of virulence of CAV inducing the apoptosis of the thymocytes and hemopoietic cells in infected chickens (Castaño et al., 2019).

The CAV's Amino Acid (A.A.) composition is extremely restrictive, with major differences in some regions in the VP1 gene called Hyper Variable Region (HVR) at 139-151 A.A. (Zhang et al., 2013). The VP1 gene is responsible for the genetic characterization of the virus, and It encodes a highly immunogenic protein responsible for the potential and 
virulence of infection (Lien et al., 2012). Three genotypes of CAV (I, II, and III) are genetically distinct and recognized based on the phylogeny of VP1 gene (Snoeck et al., 2012). Genotypes II and III are worldwide distributed, while genotype I consists alone of Australian isolates (Kim et al., 2010). Only minor mutations in amino acid sequences have been recorded in CAV viruses from various geographical positions (Ducatez et al., 2005; Kim et al., 2010). The Commercially used CAV vaccines (Cux-1N/Germany and CAV/Nobilis®P4) are derived from wild-type CAVs that are not completely attenuated; therefore, the virus can revert to virulent, and be transmitted horizontally and vertically causing clinical symptoms in young chickens (Tseng et al., 2019)

The objective of the present study was to disseminate the situation and molecular characterization of CAV circulating in Egypt during 2020 and to determine the relationship between current viruses and vaccine strains for improving the control of the virus.

\section{MATERIALS AND METHODS}

\section{Tissue specimen}

The samples were collected from 86 commercial broiler chicken farms (aged two to four weeks) located in 14 Egyptian Governorates (Beheira, Sharqia, Qalyubia, Dakahlia, Ismailia, Gharbia, Giza, Matruh, Cairo, Alexandria, Minya, Beni Suef, Sohag, Faiyum) during 2020 (Table 1 and Figure 1). Most tested broiler chicken farms were vaccinated. The samples were collected from different tissues (bone marrow, thymus, and spleen). The samples were homogenized by grinding. Twenty-five mg of various affected tissues were grounded with phosphate buffer saline (PBS) and the mixture of one $\mathrm{mg}$ streptomycin sulphate/ml and 1000 I.U. penicillin/ml using a mortar and pestle. the Freezing and thawing were carried out three times, and then it was centrifuged at $3000 \mathrm{rpm}$ for 20 minutes. Next, the supernatant was collected in a new tube and stored at -20 till used (Hirai and Shimakura, 1974).

\section{Ethical approval}

The handling of chickens was based on the ethical role of the National Animal Health and Research Institute, Giza, Egypt. The tissue samples were collected from dead chickens suffering from an infection of CAV in commercial farms. Both handling of the chickens and sampling were performed with respect to animal rights, and immediately after the confirmation of death by a veterinarian.

Table 1. The location, number, and the result of evaluated samples by PCR for detection of chicken anemia virus

\begin{tabular}{lcc}
\hline Governorate & $\begin{array}{c}\text { No. of collected } \\
\text { samples }\end{array}$ & $\begin{array}{c}\text { No. of CAV } \\
\text { positive farms }\end{array}$ \\
\hline Beheira & 10 & 5 \\
\hline Sharqia & 9 & 7 \\
\hline Qalyubia & 9 & 4 \\
\hline Dakahlia & 8 & 0 \\
\hline Ismailia & 8 & 5 \\
\hline Gharbia & 7 & 0 \\
\hline Giza & 7 & 0 \\
\hline Matruh & 5 & 0 \\
\hline Cairo & 5 & 2 \\
\hline Alexandria & 5 & 3 \\
\hline Minya & 5 & 0 \\
\hline Beni Suef & 3 & 0 \\
\hline Sohag & 3 & 0 \\
\hline Faiyum & 2 & 0 \\
\hline Total & 86 & $26(30 \%)$ \\
\hline CAV: Chicken & $5 n$ &
\end{tabular}

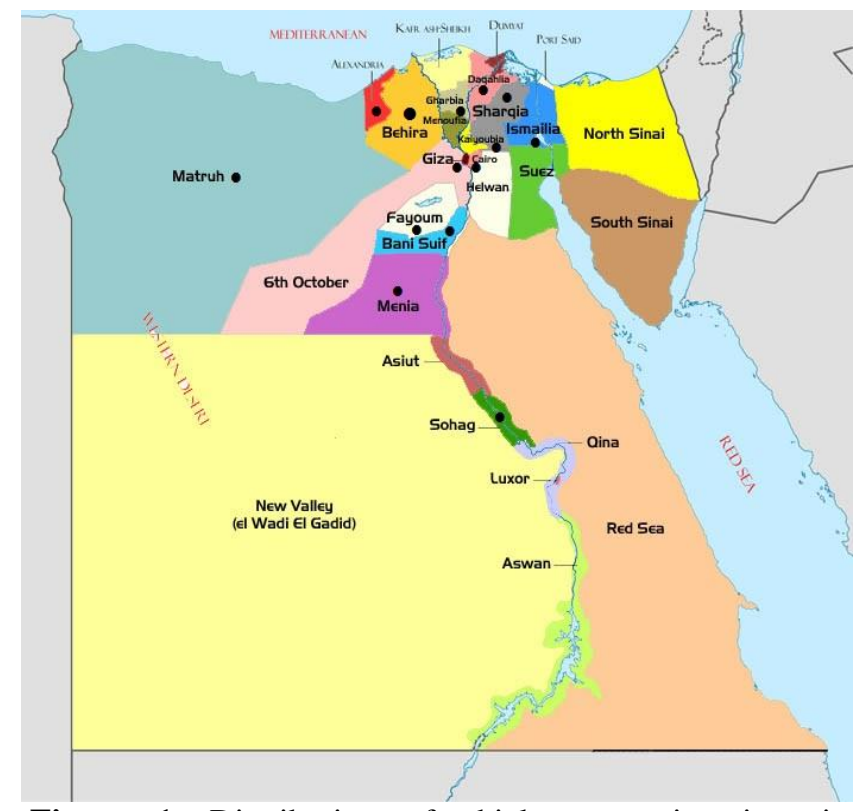

Figure 1. Distribution of chicken anemia virus in Egyptian map in 2020

\section{Detection of chicken anemia virus by PCR}

DNA was extracted from tissue homogenate by QIAmp DNA mini kit (Qiagen Inc., Valencia, Calif., USA) following the manufacturer's instructions. Amplification of partial VP1 gene was carried out by using EmeraldAmp ${ }^{\circledR}$ GT PCR kit (TaKaRa Bio, Inc., Shiga, Japan), gene-specific oligonucleotide primers (5-GAC TGT AAG ATG GCA AGA CGA GCT C-3 and 5-GGC TGA AGG ATC CCT CAT TC-3) were used (Todd et al., 1991) according to manufacturer's instructions. The specific amplified PCR product was detected by agarose gel electrophoresis.

\section{Sequencing of partial VP1 gene}

Ten positive samples were selected for partial sequencing of the VP1 gene (Table 2). The positive amplified PCR product was purified using QIAquick Gel Extraction Kit (Qiagen, Hilden, Germany). The sequence reaction was carried 
out by using BigDye Terminator v3.1 Cycle Sequencing Kit (Applied Biosystems, USA), then it was purified by using Centrisep spin column, (Thermo Fisher, USA), and the sequence collection was performed by ABI 3500 Genetic Analyzer (Life Technologies, USA).

\section{Genetic and phylogenetic studies}

The DNA sequence of the partial VP1 gene for Egyptian CAV in this study was aligned with 23 different viruses from different countries and vaccine strains (Del-Ros, Cux-1, and 26PA) from the National Centre in Biotechnology Information (NCBI) by using Bio-Edit software clustal W (Hall, 1999). The Phylogenetic tree was made by using the Neighbor-Joining method in MEGA 6 with 1,000 bootstrap replications (Tamura et al., 2013). The genetic distance among different viruses was carried out using DNASTAR Lasergene 9 (Madison, WI, USA). The viruses in the present study were published in National Center for Biotechnology Information (NCBI) under accession number (Table 2).

Table 2. Governorates and Genbank accession number of partial VP1gene sequence of 10 chicken anemia virus selected samples

\begin{tabular}{cccc}
\hline No. & Code & Governorate & Accession number \\
\hline 1 & A-Egypt-AN1-2020 & $\underline{\text { Beheira }}$ & MW286460 \\
\hline 2 & A-Egypt-AN2-2020 & $\underline{\text { Sharqia }}$ & MW286461 \\
\hline 3 & A-Egypt-AN3-2020 & $\underline{\text { Alexandria }}$ & MW286462 \\
\hline 4 & A-Egypt-AN4-2020 & $\underline{\text { Cairo }}$ & MW286463 \\
\hline 5 & A-Egypt-AN5-2020 & $\underline{\text { Sharqia }}$ & MW286464 \\
\hline 6 & A-Egypt-AN6-2020 & $\underline{\text { Qalyubia }}$ & MW286465 \\
\hline 7 & A-Egypt-AN7-2020 & $\underline{\text { Beheira }}$ & MW286466 \\
\hline 8 & A-Egypt-AN8-2020 & $\underline{\text { Beheira }}$ & MW286467 \\
\hline 10 & A-Egypt-AN9-2020 & $\underline{\text { Sharqia }}$ & MW286468 \\
\hline
\end{tabular}

\section{RESULTS}

\section{Clinical signs and gross pathology}

The gross examination showed that there were infected flocks suffering from stunting, depression, poor growth, weakness, mild drop in egg production with mortality rates ranging from 5\% to $15 \%$. While the complete necropsy examinations revealed paleness in bone marrow and liver, atrophy of bursa of Fabricius and thymus. Subcutaneous hemorrhage was also observed in some cases. It was similar to clinical signs findings of Swayne et al. (2019).

\section{Detection of chicken anemia virus by PCR}

Out of 86 tested tissue samples, 26 samples were CAV positive at the correct size band of 675 bp with an incidence rate of $30 \%$ (Table 1). All positive samples were recorded in six governorates (Beheira, Sharqia, Alexandria, Cairo, Ismailia, Qalyubia) in Lower Egypt with the highest incidence in Sharqia, Ismailia, and Alexandria $(78 \%, 62.5 \%$, and $60 \%$, respectively), and the lowest incidence in Cairo (40\%).

\section{Genetic characterization of VP1 gene of chicken anemia virus}

The nucleotide and amino acid sequence of VP1 gene of selected 10 positive samples of CAV located in six governorates (Beheira, Sharqia, Alexandria, Cairo, Ismailia, Qalyubia) were aligned with different CAV viruses and vaccine strains from the National Centre in Biotechnology Information (NCBI) By using Bioedit clustal W software (Hall, 1999), and The Phylogenetic tree was made by using the Neighbor-Joining method in MEGA 6 with 1,000 bootstrap replications (Tamura et al., 2013). The phylogenetic tree showed that VP1 gene of CAV was divided into two groups (A, B) distinct from vaccine strains (Del-Ros, Cux-1, and 26PA) that were clustered in group C. The seven Egyptian viruses (A/Egypt/AN1/2020 to A/Egypt/AN7/2020) were clustered with G6/Japan/AB119448.1, ArgA00213/Argentina/EU871783.1 and SMSC-1/Malaysia/AF285882.1 in group A in a new subgroup 2A, but the other three viruses (Egypt/AN8/2020, Egypt/AN9/2020 and Egypt/AN10/2020) were clustered with NIE/19.04/118/Nigeria and CAV-B/India in the group B in a new subgroup 2B as shown in Figure 2.

By mutation analysis of partial VP1 gene sequence including the hypervariable region (139-151) comparing with Del-Rose reference strains, the V75I, M97L, K139Q, and E144Q mutations were recorded in all viruses related to group $\mathrm{A}$ and $\mathrm{B}$. The last two mutations were included in the hypervariable region. All Egyptian viruses in the current study had specific new mutations at Y13N and H22N. In addition, the seven Egyptian viruses related to group 2A had G74E and $\mathrm{I} 83 \mathrm{~V}$ in A/Egypt/AN1/2020, A/Egypt/AN2/2020, A/Egypt/AN4/2020 and S140Ain in A/Egypt/AN1/2020, $\mathrm{A} /$ Egypt/AN2/2020, A/Egypt/AN4/2020 and A/Egypt/AN5/2020. The last one is included in the hypervariable region as shown in Table 3. 


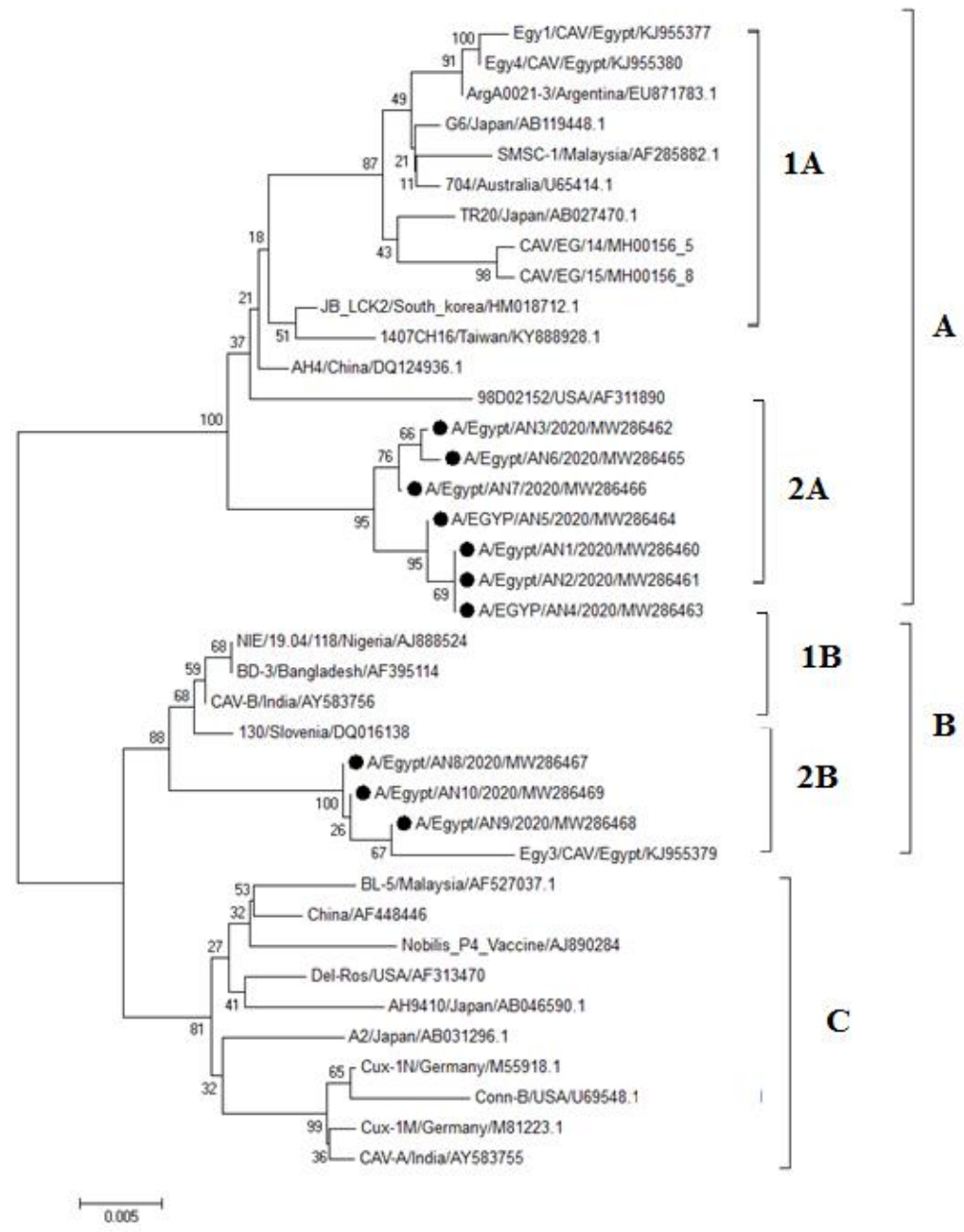

Figure 2. Phylogenetic tree of the partial VP1 gene sequence of chicken anemia virus. FN: The figure shows the phylogenetic analysis of VP1 gene of CAV revealing that all Egyptian viruses were clustered into two groups (A, B) in a new subgroup $(2 \mathrm{~A}, 2 \mathrm{~B})$ that was distinct from vaccine strains that were clustered in group $\mathrm{C}$. The CAV viruses in the present study are indicated with a black dot.

Table 3. Numbers of amino acid substitution of partial VP1 gene sequence comparing with Del-Rose reference strains

\begin{tabular}{|c|c|c|c|c|c|c|c|c|c|c|}
\hline \multirow{2}{*}{ Strain name } & \multirow{2}{*}{ Genotype } & \multicolumn{9}{|c|}{ Number of amino acid in VP1 gene } \\
\hline & & 13 & 22 & 74 & 75 & 83 & 97 & 139 & 140 & 144 \\
\hline Del-Ros/USA/AF313470 (Refrence strain) & $\mathrm{C}$ & $\underline{Y}$ & $\underline{\mathrm{H}}$ & $\underline{\mathrm{G}}$ & $\underline{\mathrm{V}}$ & $\underline{\mathrm{I}}$ & $\underline{\mathrm{M}}$ & $\underline{\mathrm{K}}$ & $\underline{\mathrm{S}}$ & $\underline{E}$ \\
\hline SMSC-1/Malaysia/AF285882.1 & $1 \mathrm{~A}$ & - & - & - & $\underline{I}$ & - & $\underline{\mathrm{L}}$ & $\underline{Q}$ & - & $\underline{Q}$ \\
\hline AH9410/Japan/AB046590.1 & $1 \mathrm{~A}$ & - & - & - & $\underline{I}$ & - & $\underline{\mathrm{L}}$ & Q & - & Q \\
\hline ArgA00213/Argentina/EU871783.1 & $1 \mathrm{~A}$ & - & - & - & $\underline{\mathrm{I}}$ & - & $\underline{\mathrm{L}}$ & $\underline{Q}$ & - & $\underline{Q}$ \\
\hline A/Egypt/AN1/2020 & $2 \mathrm{~A}$ & $\underline{\mathrm{N}}$ & $\underline{\mathrm{N}}$ & $\underline{\mathrm{E}}$ & $\underline{I}$ & $\underline{\mathrm{V}}$ & $\underline{\mathrm{L}}$ & $\underline{Q}$ & $\underline{\mathrm{A}}$ & Q \\
\hline A/Egypt/AN2/2020 & $2 \mathrm{~A}$ & $\underline{\mathrm{N}}$ & $\underline{\mathrm{N}}$ & $\underline{\mathrm{E}}$ & $\underline{I}$ & $\underline{\mathrm{V}}$ & $\underline{\mathrm{L}}$ & $\underline{Q}$ & $\underline{\mathrm{A}}$ & $\underline{Q}$ \\
\hline A/Egypt/AN3/2020 & $2 \mathrm{~A}$ & $\underline{\mathrm{N}}$ & $\underline{\mathrm{N}}$ & $\underline{\mathrm{E}}$ & $\underline{I}$ & $=$ & $\underline{\mathrm{L}}$ & $\underline{Q}$ & $=$ & $\underline{Q}$ \\
\hline A/Egypt/AN4/2020 & $2 \mathrm{~A}$ & $\underline{\mathrm{N}}$ & $\underline{\mathrm{N}}$ & $\underline{\mathrm{E}}$ & $\underline{I}$ & $\underline{\mathrm{V}}$ & $\underline{\mathrm{L}}$ & $\underline{Q}$ & $\underline{\mathrm{A}}$ & $\underline{Q}$ \\
\hline A/Egypt/AN5/2020 & $2 \mathrm{~A}$ & $\underline{\mathrm{N}}$ & $\underline{\mathrm{N}}$ & $\underline{\mathrm{E}}$ & $\underline{I}$ & $=$ & $\underline{\mathrm{L}}$ & $\underline{Q}$ & $\underline{\mathrm{A}}$ & $\underline{Q}$ \\
\hline A/Egypt/AN6/2020 & $2 \mathrm{~A}$ & $\underline{\mathrm{N}}$ & $\underline{\mathrm{N}}$ & $\underline{E}$ & $\underline{\mathrm{I}}$ & $=$ & $\underline{\mathrm{L}}$ & Q & $=$ & $\underline{Q}$ \\
\hline A/Egypt/AN7/2020 & $2 \mathrm{~A}$ & $\underline{\mathrm{N}}$ & $\underline{\mathrm{N}}$ & $\underline{E}$ & $\underline{I}$ & z & $\underline{\mathrm{L}}$ & $\underline{Q}$ & $=$ & Q \\
\hline CAV-A/India/AY583755 & 1B & - & - & - & $\underline{I}$ & - & $\underline{\mathrm{L}}$ & $\underline{Q}$ & - & $\underline{Q}$ \\
\hline BD-3/Bangladesh/AF395114 & 1B & - & - & - & $\underline{I}$ & - & $\underline{\mathrm{L}}$ & $\bar{Q}$ & - & $\bar{Q}$ \\
\hline NIE/19.04/118/Nigeria/AJ888524 & 1B & - & - & - & $\underline{I}$ & - & $\underline{\mathrm{L}}$ & Q & - & Q \\
\hline A/Egypt/AN8/2020 & $2 \mathrm{~B}$ & $\underline{\mathrm{N}}$ & $\underline{N}$ & - & $\underline{I}$ & - & $\underline{\mathrm{L}}$ & $\underline{Q}$ & - & $\underline{Q}$ \\
\hline A/Egypt/AN9/2020 & $2 \mathrm{~B}$ & $\underline{\mathrm{N}}$ & $\underline{\mathrm{N}}$ & - & $\underline{I}$ & - & $\underline{\mathrm{L}}$ & $\underline{Q}$ & - & $\underline{Q}$ \\
\hline A/Egypt/AN10/2020 & $2 \mathrm{~B}$ & $\underline{\mathrm{N}}$ & $\underline{\mathrm{N}}$ & - & $\underline{I}$ & - & $\underline{\mathrm{L}}$ & $\underline{Q}$ & - & Q \\
\hline Nobilis P4 Vaccine/AJ890284 & $\mathrm{C}$ & - & - & - & - & - & - & - & - & - \\
\hline
\end{tabular}

A: Alanine, E: Glutamic acid, G: Glycine, H: Histidine, I: Isoleucine, K: Lysine, L: Lysine, M: Methionine, N: Asparagines, Q: Glutamine, S: Serine, V: Valine, Y: Tyrosine. The A.A. identity showed that the seven Egyptian viruses (A/Egypt/AN1/2020 to A/Egypt/AN7/2020) had a high identity percent (97 to 97.9\%) with G6/Japan/AB119448.1, ArgA0021-3/Argentina/EU871783.1, and SMSC-1/Malaysia/AF285882, and the other three Egyptian viruses (A/Egypt/AN8/2020, A/Egypt/AN9/2020, A/Egypt/AN10/2020) had a high identity percent (97.3-98.7\%) with BD-3/Bangladesh and NIE/19.04/118/Nigeria. The A.A. identity percent among Egyptian viruses in the subgroup 2A and $2 \mathrm{~B}$ in the current study and vaccine strains used in Egypt (Cux-1, Del-Ros, and 26PA) was 94.8 to $95.7 \%$ A.A. and $97-97.8 \%$ A.A. respectively as shown in Figure 3. 


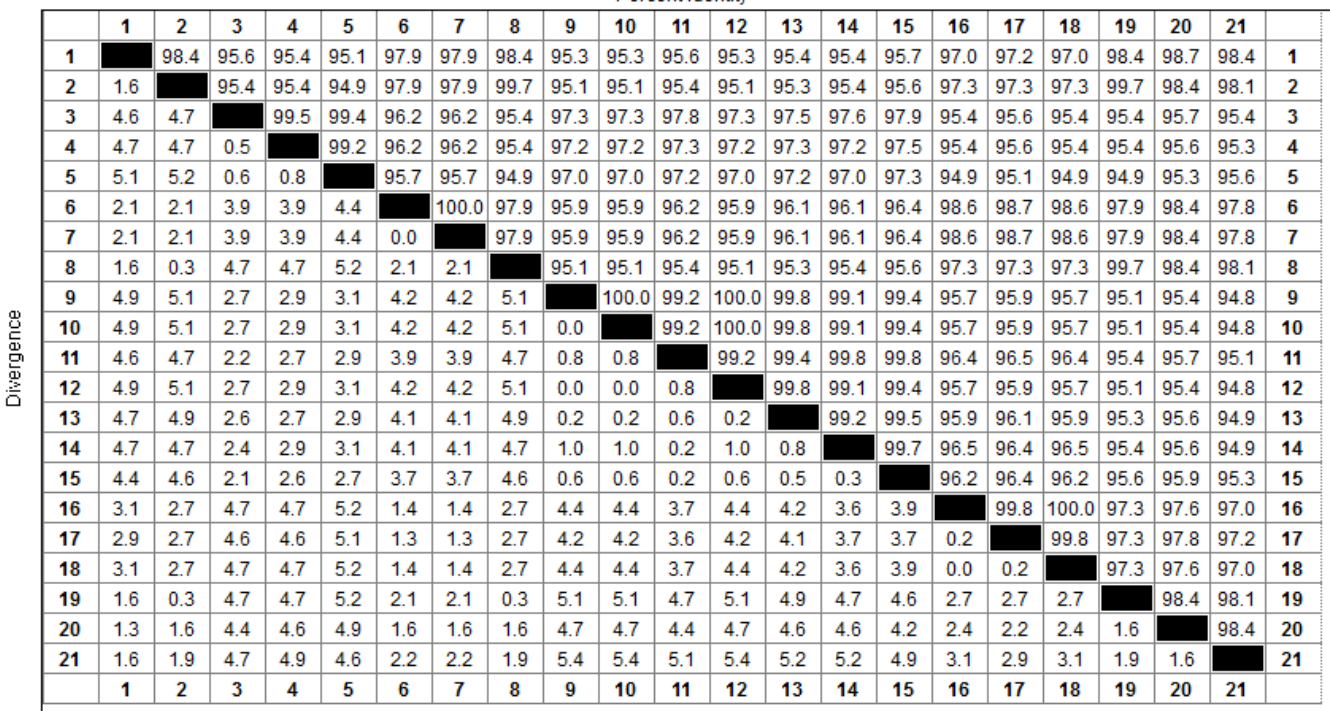

A2-Japan-AB031296.1

Cux-1M-Germany-M81223. 1 G6-Japan-AB119448.1 ArgA0021-3-Argentina-EU871783. SMSC-1-Malaysia-AF285882.1 BD-3-Bangladesh-AF395114 NIE-19.04-118-Nigeria-AJ888524 CAV-A-India-AY583755

A-Egypt-AN1-2020-MW286460 A-Egypt-AN2-2020-MW286461 A-Egypt-AN3-2020-MW286462 A-EGYP-AN4-2020-MW286463 A-EGYP-AN5-202-MW286464 A-Egypt-AN6-2020-MW286465 A-Egypt-AN7-2020-MW286466 A-Egypt-AN8-2020-MW286467 A-Egypt-AN9-2020-MW286468 A-Egypt-AN10-2020-MW286469 Cux-1N-Germany-M55918.1

Del-Ros-USA-AF313470

Nobilis-P4-Vaccine-AJ890284

Figure 3. Amino acid identities of VP1 gene of CAV compared to other selected viruses and vaccines' strains. FN: The A.A. identity percent among Egyptian viruses in the subgroup 2A and 2B in the current study and vaccine strains used in Egypt (Cux-1, Del-Ros, and 26PA) was 94.8 to $95.7 \%$ A.A. and $97-97.8 \%$ A.A. respectively.

\section{DISCUSSION}

Chicken anemia virus worldwide is an immunosuppressive disease that circulates in several countries (Natesan et al., 2006; Zhang et al., 2013). In Egypt, the CAV was spread in different governorates causing high mortality and economic losses (Erfan et al., 2018). In the current study, 26 positive samples out of 86 samples were collected from different broiler chicken farms located in six out of 14 governorates in Egypt with a high incidence rate (30\%) in Lower Egypt, especially in Sharkia (78\%), Ismailia (62.5\%), and Alexandria (60\%) and most of them were vaccinated. It is an indicator for the progressive exacerbation of the disease in vaccinated broiler chicken farms in Egypt during 2020 with a high mortality rate that ranged from 5 to 15 percent.

The VP1 gene sequence is extremely important to determine the virulence of the virus, cell infection ability, viral replication, and the relationship among CAV viruses especially the N-terminal half of VP1 gene that contains the hypervariable region from 139 to 151 A.A. (Renshaw et al., 1996; Islam et al., 2002; Negasi et al., 2008). These hypervariable regions are the most variable region in the VP1 gene of chicken anemia virus as previously mentioned by Islam et al. (2002). Phylogenetically, the VP1 gene was divided into many groups in the world that can easily identify the field and vaccines' strains (Eltahir et al., 2011)

As previously recorded the CAV circulated in Egypt from different genotypes may be due to multiple introductions (AboElkhair et al., 2014; Abdel-Mawgod et al., 2018; Erfan et al., 2018). In the current study, ten viruses were selected from six different governorates to be sequenced for partial VP1 gene and to be compared with viruses isolated from many countries, such as Germany, India, Japan, Nigeria, Bangladesh, USA, Korea, Taiwan, and China (Schat, 2009). All Egyptian viruses in the current study related only to field viruses. The vaccine strains were not recorded. In the present study, the seven viruses were related to the viruses from Japan, Argentina, and Malaysia as previously recorded (AboElkhair et al., 2014; Abdel-Mawgod et al., 2018; Erfan et al., 2018). but the Egyptian viruses in the study were acquired new mutations cluster them in a new subgroup 2A and the other three Egyptian viruses were related to the viruses from Nigeria, India with new mutations cluster them in a new subgroup 2B. These findings indicated continuous circulation of multiple genotypes of CAV in Egypt with multiple evolutions in the VP1.

By A.A. mutation analysis, the viruses related to group A and B had A. A mutation at V75I, M97L, K139Q, E144Q when comparing with DEL-Rose vaccine strain as previously described by AboElkhair et al. (2014) and Erfan et al. (2018). The 139Q and 144Q could decrease the efficacy of the replication in the cell culture (Renshaw et al., 1996). In the current study, the Egyptian viruses had a specific new mutation. The Y13N, H22N were recorded in all Egyptian strains in our study and G74E, were recorded in subgroup 2A and I83V in A/Egypt/AN1/2020, A/Egypt/AN2/2020, A/Egypt/AN4/2020, and S140Ain in A/Egypt/AN1/2020, A/Egypt/AN2/2020, A/Egypt/AN4/2020 and A/Egypt/AN5/2020. The H22N was recoded by AboElkhair et al. (2014) in one Egyptian virus that was important in distinguishing the strain of CAV. Further studies are needed to work on the effect of these mutations in the pathogenicity of the virus and they may be the cause of outbreaks in vaccinated farms.

Recently, multiple vaccines are used (mainly Del-Ros, Nobilis P4, and Cux-1 strains) for breeder flocks producing maternal antibodies to newly born chickens which give protection till two to three weeks old (Haridy et al., 2009; Prezotto et al., 2016). The phylogenetic analysis and A.A. identity showed that the field viruses were distinct from the 
vaccines' strains as previously recorded by AboElkhair et al. (2014) and Erfan et al. (2018). It explains the occurred infection of the vaccinated flocks by CAV as mentioned by Abdel-Mawgod et al. (2018) and Erfan et al. (2018). Further study is needed to determine the vaccine efficacy against the field stains.

\section{CONCLUSION}

The chicken anemia virus was widely circulated with a high incidence in Lower Egypt in six governorates. The phylogenetic tree of the partial VP1 gene during the present study indicated the Egyptian virus were clustered in two groups (A, B) with a newly acquired mutation specific to Egyptian viruses forming new subgroups (2A, 2B). The field virus in the current study was genetically distinct from vaccine strains. Continuous monitoring on the genetic evolution of $\mathrm{CAV}$ and further studies are required to work on the effect of acquired mutations on the pathogenicity of the virus and the vaccine efficacy.

\section{DECLARATIONS}

\section{Competing interests}

The authors declare that they have no conflict of interest.

\section{Authors' contribution}

Ahmed Abd Elhalim Mohammed and Abdelhafez Samir carried out tissue specimen collection from the affected flocks, detection of the DNA of Chicken anemia virus and analysis of the data, and wrote the manuscript. Nahed Yehia carried out the sequencing of partial VP1 gene, genetic and phylogenetic analysis, and analysis of the data. All authors read and approved the final manuscript.

\section{Ethical consideration}

Ethical issue including plagiarism, consent to public misconduct, data fabrication and/or falsification, double publication and/or submission, redundancy has been checked by the authors

\section{REFERENCES}

Abdel-Mawgod S, Adel A, Arafa AS, and Hussein HA (2018). Full genome sequences of chicken anemia virus demonstrate mutations associated with pathogenicity in two different field isolates in Egypt. Virus Disease, 29(3): 333-341. DOI: https://www.doi.org/10.1007/s13337-018-0467-z.

Aboelkhair M, El-Razak A, and Metwally A (2014). Molecular characterization of chicken anemia virus circulating in chicken flocks in Egypt. Advances in Virology, Article ID 797151. DOI: https://www.doi.org/10.1155/2014/797151

Castaño P, Benavides J, Lee MS, Fernández M, Fuertes M, Royo M, Fernández JM, Pérez V, and Ferreras MC (2019). Tissue tropism of chicken anaemia virus in naturally infected broiler chickens. Journal of Comparative Pathology, 167: 32-40. DOI: https://www.doi.org/10.1016/j.jcpa.2018.11.008

Cheng JH, Lai GH, Lien YY, Sun FC, Hsu SL, Chuang PC, and Lee MS (2019). Identification of nuclear localization signal and nuclear export signal of VP1 from the chicken anemia virus and effects on VP2 shuttling in cells. Virolology Journal, 16(1): Article number 45. DOI: https://www.doi.org/10.1186/s12985-019-1153-5

Craig MI, Rimondi A, Delamer M, Sansalone P, König G, Vagnozzi A, and Pereda A (2009). Molecular characterization of chicken infectious anemia virus circulating in Argentina during 2007. Avian Disease, 53(3): 331-335.DOI: https://www.doi.org/10.1637/8478-100808-Reg.1.

Ducatez MF, Owoade AA, Abiola JO, and Muller CP (2005). Molecular epidemiology of chicken anemia virus in Nigeria. Archieve Virology, 151: 97-111. https://www.doi.org/10.1007/s00705-005-0609-7

Eltahir YM, Qian K, Jin W, and Qin A (2011). Analysis of chicken anemia virus genome: evidence of intersubtype recombination. Virolology Journal, 8: 512-512. DOI: https://www.doi.org/10.1186/1743-422X-8-512.pdf.

Erfan AM, Selim AA, and Naguib MM (2018). Characterization of full genome sequences of chicken anemia viruses circulating in Egypt reveals distinct genetic diversity and evidence of recombination. Virus Research, 251: 78-85 DOI: https://www.doi.org/10.1016/j.virusres.2018.05.008.

Hall TA (1999). Bio Edit: A user-friendly biological sequence alignment editor and analysis for Windows 95/98/NT. Nucleic Acids Symposium Series, 41: 95-98. Available at: https://www.sid.ir/en/journal/JournalList.aspx?ID=5696

Haridy M, Goryo M, Sasaki J, and Okada K (2009). Pathological and immunohistochemical study of chickens with co-infection of Marek's disease virus and chicken anaemia virus. Avian Pathology, 38(6): 469-483. DOI: https://www.doi.org/10.1080/03079450903349162.

Hirai K, and Shimakura S (1974). Structure of infectious bursal disease virus. Journal of Virology, 14: 957-964. Available at: https://www.ncbi.nlm.nih.gov/pmc/articles/PMC355603/\#: :text=The\%20buoyant\%20density\%20of\%20infectious,diameter\%20 and $\% 20$ had $\% 20$ no\%20envelope.

Islam MR, Johne R, Raue R, Todd D, and Müller H (2002). Sequence analysis of the full length cloned DNA of a chicken anaemia virus (CAV) strain from Bangladesh: Evidence for genetic grouping of CAV strains based on the deduced VP1 amino acid 
sequences. Journal of Veterinary Medicine Series B, 49(7): 332-337. DOI: https://www.doi.org/10.1046/j.14390450.2002.00581.x.

Kim HR, Kwon YK, Bae YC, Oem JK, and Lee OS (2010). Molecular characterization of chicken infectious anemia viruses detected from breeder and broiler chickens in South Korea. Poultry Science, 89(11): 2426-2431. DOI https://www.doi.org/10.3382/ps.2010-00911.

Lai GH, Lin MK, Lien YY, Cheng JH, Sun FC, Lee MS, Chen HJ, and Lee MS (2018). Characterization of the DNA binding activity of structural protein VP1 from chicken anaemia virus. BMC Vetrinary Reseach, 14: Article number 155. DOI: https://www.doi.org/10.1186/s12917-018-1465-5.

Lien YY, Huang CH, Sun FC, Sheu SC, Lu TC, Lee MS, Hsueh SC, Chen HJ, and Lee MS (2012). Development and characterization of a potential diagnostic monoclonal antibody against capsid protein VP1 of the chicken anemia virus. Journal of Veterinary Science, 13: 73-79. DOI: https://www.doi.org/10.4142/jvs.2012.13.1.73.

Miller MM, and Schat KA (2004). Chicken Infectious Anemia virus: An example of the ultimate host-parasite relationship. Avian Disease, 48: 734-745. DOI: https://www.doi.org/10.1637/7271-090304R.

Natesan S, Kataria JM, Dhama K, Rahul S, and Baradhwaj N (2006). Biological and molecular characterization of chicken anaemia virus isolates of Indian origin. Virus Research, 118: 78-86. DOI: https://www.doi.org/10.1016/j.virusres.2005.11.017.

Negasi Z, Omar AR, Hair-Bejo M, and Giap TC (2008). Detection and characterization of chicken anemia virus from commercial broiler breeder chickens. Virology Journal, 5: Article number 128. DOI: https://www.doi.org/10.1186/1743-422X-5-128.

Peters MA, Crabb BS, Washington EA, and Browning GF (2006). Site-directed mutagenesis of the VP2 gene of chicken anemia virus affects virus replication, cytopathology and host-cell MHC class I expression. 1996. Journal of General Virology, 87(4): 823-831. DOI: https://www.doi.org/10.1099/vir.0.81468-0.

Prezotto C, Marin S, Araújo T, Barbosa F, Barrios P, Gomes A, Peconick A, Resende M, Sousa R, and Martins N (2016). Experimental coinfection of chicken anemia virus and mycoplasma gallisepticum vaccine strains in broiler chicks. Brazilian Journal of Poultry Science, 18: 475-480. DOI: https://www.doi.org/10.1590/1806-9061-2016-0235

Renshaw RW, Soiné C, Weinkle T, O’Connell PH, Ohashi K, Watson S, Lucio B, Harrington S, and

Schat KA (1996). A hypervariable region in VP1 of chicken infectious anemia virus mediates rate of spread and cell tropism in tissue culture. Journal of Virology, 70: 8872-8878. DOI: https://www.doi.org/10.1128/JVI.70.12.8872-8878.1996.

Rosario K, Breitbart M, and Harrach B (2017). Revisiting the taxonomy of the family Circoviridae: establishment of the genus Cyclovirus and removal of the genus Gyrovirus. Archives of Virology, 162(5):1447-1463. DOI: https://www.doi.org/10.1007/s00705-017-3247-y

Schat KA (2009). Chicken anemia virus. Current Topics in Microbiology and Immunology, 331: 151-183. DOI: https://www.doi.org/10.1007/978-3-540-70972-5_10.

Snoeck CJ, Komoyo GF, Mbee BP, Nakouné E, Le Faou A, Okwen MP, and Muller CP (2012). Epidemiology of chicken anemia virus in Central African Republic and Cameroon. Virology Jornal, 9(1): Article number 189. DOI: https://www.doi.org/10.1186/1743-422X-9-189

Swayne DE, Boulianne M, Catherine ML, Larry RM, Venugopal N, Suarez DL, Sjaak W, and Grimes T (2019). Disease of Poultry. 4th edition. Chapter 8. Available at: https://dokumen.pub/diseases-of-poultry-fourteenth-edition-9781119371168$\underline{1119371163 . h t m l}$

Tamura G, Stecher D, Peterson A, Filipski, and Kumar S (2013). MEGA6: Molecular evolutionary genetics analysis version 6.0. Molecular Biology and Evolution, 30(12): 2725-2729. DOI: https://www.doi.org/10.1093/molbev/mst197.

Todd D, Niagro FD, Ritchie BW, Curran W, Allan GM, Lukert PD, Latimer KS, Steffens WL, and McNulty MS (1991). Comparison of three animal viruses with circular single-stranded DNA genomes. Archieve Virology, 117: 129-135. DOI: https://www.doi.org/10.1007/BF01310498

Tseng TY, Liu YC, Hsu YC, Chang PC, Hsieh MK, Shien JH, and Ou SC (2019). Preparation of chicken anemia virus (CAV) viruslike particles and chicken interleukin-12 for vaccine development using a baculovirus expression system. Pathogens, 8(4): Article number 262. DOI: https://www.doi.org/10.3390/pathogens8040262.

Yuasa N, Taniguchi T, and Yoshida I (1979). Isolation and some characteristics of an agent inducing anemia in chicks. Avian Disease, pp. 366-385. Available at: https://www.jstor.org/stable/1589567?origin=crossref\&seq=1\#metadata_info_tab_contents

Zhang X, Liu Y, Wu B, Sun B, Chen F, Ji J, Ma J, and Xie Q (2013). Phylogenetic and molecular characterization of chicken anemia virus in southern China from 2011 to 2012. Scientific Reports, 3: Article number $3519 . \quad$ DOI: https://www.doi.org/10.1038/srep03519 